\title{
Analisis Reaksi Investor di Bursa Efek Indonesia pada Pelantikan Joko Widodo
}

\author{
Komang Lia Karina*1, I Nyoman Sujana², M. Rudi Irwansyah³ \\ Program Studi Pendidikan Ekonomi \\ Universitas Pendidikan Ganesha \\ Singaraja, Indonesia
}

Riwayat Artikel

Tanggal diajukan:

5 Desember 2019

Tanggal diterima :

4 Juni 2020

Tanggal

dipublikasikan:

29 Juni 2020
Pengutipan:

Karina, K. L.

Sujana, I. N. \& Irwansyah, M. R.

(2020). Analisis

Reaksi Investor di

Bursa Efek

Indonesia (Event

Study Terhadap

Pelantikan

Presiden Ke-8).

Jurnal Pendidikan

Ekonomi

Undiksha, 12 (1),

50-59

\section{e-mail: liakarina1998@gmail.com¹, sujanatbn@yahoo.com¹, rudi.irwansyah@undiksha.ac.id²}

\begin{abstract}
Abstrak
Tujuan penelitian ini untuk menganalisis reaksi investor di Bursa Efek Indonesia terhadap peristiwa pelantikan Presiden ke-8 dengan melihat ada tidaknya perbedaan abnormal return dan aktivitas volume perdagangan saham pada saat sebelum dan sesudah peristiwa tersebut secara signifikan. Periode pengamatan yang digunakan pada penelitian ini selama 10 hari, dengan rincian masing-masing 5 hari saat sebelum dan sesudah peristiwa pelantikan Presiden yang terjadi pada tanggal 20 Oktober 2019. Penelitian ini merupakan jenis penelitian kuantitatif dengan memakai data transaksi harian di pasar modal sebagai sumber data sekunder. Sampel yang digunakan adalah perusahan-perusahaan yang termasuk ke dalam indeks saham LQ45 periode Agustus 2019 - Januari 2020. Pengujian hipotesis ini menggunakan uji non-parametrik berupa uji wilcoxon. Hasil penelitian menunjukkan bahwa tidak terdapat perbedaan secara signifikan pada abnormal return dan aktivitas volume perdagangan saham periode sebelum dan sesudah peristiwa tersebut. Hal ini dibuktikan oleh nilai probabilitas di atas taraf signifikansi sebesar $5 \%$. Sehingga, hasil penelitian ini menyatakan bahwa tidak adanya reaksi investor terhadap peristiwa pelantikan Presiden ke-8 di Indonesia.
\end{abstract}

Kata Kunci: abnormal return; aktivitas volume; perdagangan saham; reaksi investor; pelantikan presiden

\begin{abstract}
This study aimed to analyze the reaction of investors on Indonesia Stock Exchange to the inauguration of the 8th President by observing whether there were any significant differences in abnormal returns and stock trading volume activities before and after the event. The observation period used in this study was 10 days, with details of each 5 days before and after the President's inauguration event that occurred on 20 October 2019. This research was quantitative research and used daily transaction data on the market capital as a secondary data source. The samples used were companies that were included in the LQ45 stock index for the period August 2019 - January 2020. A non-parametric test in the form of Wilcoxon test was used to test the hypothesis. The results of this study showed that there were no significant difference in abnormal return and stock trading volume activity in the period before and after the event. This was evidenced by the probability value above the significance level of 5\%. Thus, the results of this study were stated that there was no reaction from the investor related to the event of the inauguration of the 8th President in Indonesia.
\end{abstract}

Keywords: abnormal returns; volume activities; stock trading; investor reaction, presidential inauguration 


\section{PENDAHULUAN}

Pada era globalisasi ini menunjukkan adanya kegiatan industri dan perdagangan secara dinamis menuntut dana yang cukup dan menyebabkan timbulnya suatu perubahan secara signifikan di segala bidang kehidupan. Salah satu cara yang mulai dilakukan orang-orang dalam bertransaksi ekonomi yaitu dengan cara menginvestasikan dana atau uangnya melalui pasar modal. Pasar modal merupakan pilar penting yang dapat mendukung perekonomian dunia termasuk juga di Indonesia. Indonesia telah mengalami perkembangan pada pasar modalnya dengan ditandai oleh peningkatan jumlah perusahaan yang telah menawarkan sahamnya ke publik dan perusahaan tersebut telah tercatat di pasar bursa sebagai perusahaan go public sehingga hal ini yang menunjukkan bahwa semakin berkembangnya pasar modal di Indonesia (Sihotang \& Mekel, 2014). Selain itu, banyaknya kegiatan investasi yang dilakukan dalam pasar modal ini lebih menguntungkan bagi pihak yang melakukan kegiatan investasi dengan dana lebih daripada melakukan penyimpanan dana di bank. Hal ini dikarenakan bahwa return yang diterima lebih tinggi dan tidak hanya itu saja pasar modal menerapkan system pengembalian dalam jangka waktu yang panjang untuk pihak yang memerlukan dana dalam kegiatan bisnisnya (Tandelilin, 2001).

Pasar modal berkaitan terhadap berbagai pengaruh atau peristiwa-peristiwa yang terjadi baik di lingkungan ekonomi ataupun non ekonomi sehingga hal ini menjadikan pasar modal sebagai instrument ekonomi (Sasongko, 2015); (Mansur \& Jumaili, 2014). Pengaruh lingkungan ekonomi dibedakan berdasarkan ruang lingkupnya yaitu mikro dan makro. Pengaruh perubahan lingkungan ekonomi mikro yang terjadi yaitu perubahan strategi perusahaan, kinerja perusahaan, pembagian dividen (Kurniawan, 2010). Sedangkan, pengaruh perubahan lingkungan ekonomi makro berdampak pada perubahan kurs pada valuta asing, terjadinya inflasi, dan adanya suatu kebijakan ekonomi yang dikeluarkan pemerintah (Alrhafynza \& Siswanto, 2017).

Peran bursa saham dalam kegiatan ekonomi semakin penting, hal tersebut akan berdampak pada bursa yang semakin sensitif terhadap peristiwa-peristiwa yang telah terjadi disekitarnya, baik yang berhubungan secara langsung maupun tidak terhadap isu ekonomi (Suryawijaya \& Setiawan, 1998). Menurut Wulan, Handayani, \& Nurlaily (2018) berbagai peristiwa yang terjadi memiliki karakteristik berbeda dan bisa mempengaruhi harga saham. Ada yang berpengaruh secara lambat (coorporate action) maupun berpengaruh secara drastis dan seketika pada waktu tertentu (insidental).

Lingkungan non ekonomi dapat memberikan pengaruh terhadap aktivitas saham di pasar bursa dan sebaliknya tidak memiliki hubungan dalam dinamika pasar modal secara langsung (Diniar \& Kiryanto, 2015). Adapun beberapa pengaruh lingkungan non ekonomi yang terjadi yaitu munculnya isu terkait dengan hak asasi manusia, kepedulian pada lingkungan hidup, dan juga peristiwa-peristiwa politik yang terjadi merupakan salah satu penyebab utama harga saham mengalami fluktuasi di bursa efek seluruh dunia (Nuryana, 2016). Peristiwa politik yang terjadi dapat berpengaruh positif maupun negative pada kestabilan iklim investasi, sehingga tingkat kepercayaan investor bisa berpengaruh kepada investor dalam negeri maupun luar negeri untuk melakukan kegiatan investasi di pasar modal (Ramesh \& Rajumesh, 2015). Waterschoot (2013) menyatakan bahwa melalui peran media massa maka peristiwa politik yang terjadi serta pasar keuangan keduanya dapat saling mempengaruhi satu sama lain.

Beberapa peristiwa politik yang telah terjadi pada tahun 2019 yaitu pada tanggal 17 April 2019 dilaksanakan Pemilu Presiden dan juga Pemilu Legislatif. Kemudian pada tanggal 21 Mei 2019 dini hari, Panitia Komisi Pemilihan Umum (KPU) Republik Indonesia berhasil menyelesaikan kegiatan perhitungan suara dengan hasil akhir yang menyatakan pasangan dengan nomor urut 1 , atas nama Joko Widodo dan Ma'ruf Amin keluar sebagai pemenang 
(tirto.id). Selanjutnya pada tanggal 20 Oktober 2019 dilaksanakannya proses pelantikan Presiden Republik Indonesia ke8. Hal yang menarik dari sosok Presiden Joko Widodo adalah memiliki deretan prestasi yang sangat membanggakan dalam dunia perpolitikan di Indonesia. Terbukti beliau dulu pernah menjadi Walikota Solo selama dua periode setelah itu Gubernur DKI Jakarta dan selanjutnya menjabat sebagai Presiden Republik Indonesia dengan II periode berturut-turut yaitu pada periode I tahun 2014-2019 dan periode II tahun 2019-2024.

Jika dilihat kembali pada tanggal 9 Juli 2014 saat terjadinya peristiwa pemilihan Presiden RI, IHSG membukukan apresiasi sebesar $1,46 \%$ pada tanggal 10 Juli 2014. Kenaikan pasar saham merespon kemenangan Joko Widodo yang dikenal dengan istilah Jokowi effect. Jika dibandingkan dengan kinerja IHSG yang hanya naik sebesar $0,4 \%$ sehari setelah Pilpres 2019 tepatnya pada tanggal 18 April 2019, istilah Jokowi effect sudah sedikit memudar. Sedangkan pada saat pelantikan Joko Widodo sebagai Presiden yang dilaksanakan pada 20 Oktober 2014, dalam waktu lima hari perdagangan terakhir menjelang pelantikan Presiden IHSG meningkat sebesar $1,33 \%$. Saat mendekati hari pelantikan presiden dan wakil presiden yang dilaksanakan 20 Oktober 2019, dalam dua hari perdagangan pertama di pekan ini, IHSG baru meningkat sebesar 0,86\%. Sebaliknya pada tanggal 16 Oktober 2019, IHSG justru melemah sebesar $0,15 \%$ per akhir sesi satu (cnbcindonesia.com).

Dari data BEl tercatat pada 24 Oktober 2019 IHSG mengalami peningkatan dengan ditutup sebesar $6.339,6470$ dan perubahan sebesar 81,8410 kemudian IHSG mengalami penurunan pada 25 Oktober 2019 ditutup sebesar 6.252,3450 dengan perubahan sebesar 87,3020. Sebelum periode pelantikan presiden, pada tanggal 09 Oktober 2019 index LQ45 mengalami penurunan dengan ditutup sebesar 934,746 dan perubahan sebesar 3,2486 . Kemudian pada tanggal 10 Oktober 2019 index LQ45 kembali mengalami penurunan dengan ditutup sebesar 933,4210 dan perubahan sebesar 1,3250. Selanjutnya dari tanggal
11 Oktober 2019 index LQ45 terus mengalami peningkatan sampai periode setelah pelantikan presiden pada tanggal 24 Oktober 2019 dengan ditutup sebesar $1.011,4590$ dan perubahan sebesar 19,3370. Kemudian index LQ45 mengalami penurunan pada 25 Oktober 2019 ditutup sebesar 991,3120 dengan perubahan sebesar 20,1470. Harga saham akan mengalami peningkatan ataupun perununan akibat dari pelaku pasar modal. Jika investor bereaksi terhadap informasi maka hal ini menjadi salah satu penyebab terjadinya perubahan pada harga saham.

Dalam penelitian ini, untuk melihat reaksi investor dapat diukur dengan menggunakan dua alat ukur yaitu yang pertama adalah abnormal return dan yang kedua adalah aktivitas volume perdagangan saham. Terjadinya abnormal return disebabkan oleh fluktuasi harga saham. Apabila pihak investor mendapatkan return yang tidak sesuai dengan return yang di ekspektasikan maka akan menimbulkan terjadinya reaksi pasar dan hal ini dinamakan sebagai abnormal return. Cara yang dilakukan untuk mengukur reaksi pasar yaitu dengan cara menghitung abnormal return lalu membedakannya menjadi dua periode waktu sebelum dan sesudah peristiwa (Chordia \& Baskaran, 2000). Menurut Hartono (2010), ada atau tidaknya abnormal return ditentukan oleh reaksi investor terhadap peristiwa yang terjadi. Sehingga pengumuman dari peristiwa yang memiliki kandungan informasi dapat membuat pihak investor bereaksi dengan cepat saat pengumuman tersebut masuk ke pasar. Sebaliknya, jika pengumuman tersebut tidak memiliki kandungan informasi maka tidak ada reaksi investor.

Reaksi Investor juga dapat dilihat melalui pergerakan aktivitas perdagangan saham di pasar modal terhadap kemunculan informasi yang ada (Fama, 1991). Pihak investor dengan kekuatan tawar-menawarnya mampu mempengaruhi harga saham di pasar sekunder (Mulyono, 2000). Meningkatnya suatu permintaan dan penjualan dapat menyebabkan volume perdagangan meningkat. Namun, untuk membedakan antara berita baik atau buruk terkait peningkatan volume perdagangan 
dapat dilihat dari penyebabnya. Jika disebabkan oleh permintaan maka disebut berita baik. Sebaliknya, apabila disebabkan oleh penjualan maka dikatakan sebagai berita buruk (Suherman, Nuraisyah, \& Ahmad, 2016).

Terdapat beberapa penelitian yang telah dilakukan berkaitan dengan reaksi investor pada event study yang memiliki hasil penelitian berbeda-beda. Meidawati \& Mahendra (2004) melakukan penelitian tentang event study terhadap abnormal return dan volume perdagangan saham LQ45 dengan hasil penelitian yaitu ada perbedaan volume perdagangan saham dan abnormal return pada periode peristiwa. Namun hasil yang berbeda ditemukan oleh (Pratama, 2015) yaitu abnormal return tidak memiliki perbedaan sehingga mengakibatkan tidak ada reaksi investor terhadap peristiwa pelantikan Presiden Republik Indonesia ke-7.

Hal ini menunjukkan bahwa peristiwa politik yang terjadi mungkin dapat mempengaruhi ataupun tidak sama sekali pada harga saham dan aktivitas volume perdagangan saham di pasar modal. Oleh sebab itu, berdasarkan penjelasan latar belakang di atas serta adanya ketidakpastian dan tidak konsistenan hasil penelitian terdahulu, sehingga peneliti tertarik untuk menguji dan menganalisis apakah terdapat perbedaan abnormal return dan aktivitas volume perdagangan saham sebelum dan sesudah peristiwa pelantikan Presiden ke-8.

\section{METODE}

Rancangan penelitian yang digunakan adalah event study untuk menjelaskan bagaimana reaksi investor terhadap peristiwa pelantikan Presiden ke8. Penelitian ini menggunakan populasi dan sampel dari perusahaan yang termasuk dalam LQ45 periode Agustus 2019 Januari 2020. Apabila jumlah populasi tidak lebih dari 100, maka pengambilan jumlah sampel yang dilakukan adalah sama sebanyak jumlah populasi yang ada dan ini merupakan penelitian populasi (Arikunto, 2002).

Penelitian ini menggunakan jenis data kuantitatif yang berasal dari harga saham dan volume perdagangan saham.
Sedangkan sumber data yang digunakan adalah data sekunder yang diterima langsung oleh peneliti dari data transaksi harian di pasar modal yang dicari melalui situs www.duniainvestasi.com.

Penelitian ini menggunakan metode pengumpulan data berupa metode dokumentasi dengan cara mengumpulkan semua informasi yang berhubungan dengan data yang dibutuhkan untuk penelitian. Selain itu, penelitian ini menggunakan periode peristiwa selama 10 hari kerja yang terdiri dari $\mathrm{H}-5$ sebelum peristiwa dan $\mathrm{H}+5$ sesudah peristiwa tanggal pengumuman pelantikan presiden pada 20 Oktober 2019. Apabila penggunaan periode waktu terlalu panjang, maka dikhawatirkan akan ada pengaruh dari peristiwa lain yang akan terjadi.

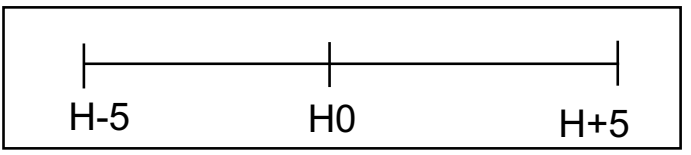

Gambar 1. Periode Peristiwa

A. Langkah-langkah yang dilakukan untuk dapat menganalisis data yaitu dengan cara menghitung terlebih dahulu abnormal return pada event window.

1. Menghitung return yang sesungguhnya (actual return).

$$
R_{i, t}=\frac{P_{i, t}-P_{i, t-1}}{P_{i, t-1}}
$$

(Hartono, 2014)

Keterangan:

$\mathrm{R}_{\mathrm{i}, \mathrm{t}}=$ actual return sekuritas $\mathrm{i}$ pada periode ke-t

$\mathrm{P}_{\mathrm{i}, \mathrm{t}}=$ harga saham penutup i pada periode ke-t

$\mathrm{P}_{\mathrm{i}, \mathrm{t}-1}=$ harga saham penutup $\mathrm{i}$ pada satu hari sebelum periode ke-t

2. Menghitung return ekspektasi (expected return.

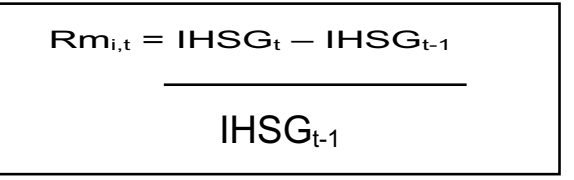

(Hartono, 2014)

Keterangan: 
p-ISSN : 2599-1418

e-ISSN : 2599-1426

$\mathrm{Rm}_{\mathrm{i}, \mathrm{t}}=\begin{aligned} & \text { Return pasar saham } \mathrm{j} \text { pada } \\ & \text { periode ke-t }\end{aligned}$

$\mathrm{IHSG}_{\mathrm{t}}=$ Indeks Harga Saham Gabungan pada periode ke-t

$\mathrm{IHSG}_{\mathrm{t}-1}=$ Indeks Harga Saham Gabungan pada satu hari sebelum periode ke-t

3. Menghitung abnormal return harian dengan persamaan sebagai berikut:

$$
A R_{i, t}=R_{i, t}-R m_{i, t}
$$

(Hartono, 2000)

Keterangan:

$\mathrm{AR}_{\mathrm{i}, \mathrm{t}}=$ abnormal return sekuritas $\mathrm{i}$ pada periode ke-t

$\mathrm{R}_{\mathrm{i}, \mathrm{t}} \quad=$ actual return sekuritas i pada periode ke-t

$\mathrm{Rm}_{\mathrm{i}, \mathrm{t}}=$ expected return sekuritas i pada periode ke-t

4. Menghitung cummulative abnormal return.

$$
\mathrm{CAR}_{\mathrm{it}}=\sum_{\mathrm{t}-1}^{\mathrm{n}} \mathrm{AR}_{\mathrm{it}}
$$

Keterangan:

$\mathrm{CAR}_{\mathrm{i}, \mathrm{t}}=$ cummulative abnormal return sekuritas i pada periode ke-t

$\mathrm{AR}_{\mathrm{i}, \mathrm{t}}=$ abnormal return sekuritas $\mathrm{i}$ pada periode ke-t

5. Menghitung average cummulative abnormal return

$$
\text { ACAR }=\underline{\sum_{\mathrm{t}-1}^{\mathrm{n}} \mathrm{CAR}_{\mathrm{it}}}
$$

(Hartono, 2014)

Keterangan:

$\mathrm{ACAR}_{\mathrm{i}, \mathrm{t}}=$ average cumulative abnormal return sekuritas i pada periode ke-t

$\mathrm{CAR}_{\mathrm{i}, \mathrm{t}}=$ cummulative abnormal return sekuritas i pada periode ke-t

B. Langkah selanjutnya adalah menghitung volume perdagangan saham sebagai berikut.

1) Menurut Foster (1986), menghitung Trading Volume Activity saham I pada hari ke-t sebagai berikut.

$$
T V A_{i, t}=\frac{\sum V t_{i, t}}{\sum V_{i, t}}
$$

Jurnal Pendidikan Ekonomi Undiksha

Vol. 12 No. 1 (2020)

Keterangan:

$\mathrm{TVA}_{\mathrm{i}, \mathrm{t}}=$ aktivitas volume perdagangan saham I pada hari ke-t

$\sum \mathrm{Vt}_{\mathrm{i}, \mathrm{t}} \quad=$ jumlah saham I yang diperdagangkan pada waktu ke-t

$\sum \mathrm{V}_{\mathrm{i}, \mathrm{t}} \quad=$ jumlah saham I yang beredar pada waktu ke-t

2. Menghitung rata-rata TVA sebelum dan sesudah Pelantikan Presiden sebagai berikttartono, 2000)

$$
\begin{gathered}
\text { ATVA }_{\text {before }}=\frac{\sum_{t=-5}^{\mathrm{t}=-1} \mathrm{TVA}_{\text {before }}}{n} \\
\text { ATVA }_{\text {after }}=\frac{\sum_{\mathrm{t}=+5}^{\mathrm{t}=+1} \mathrm{TVA}_{\text {after }}}{n}
\end{gathered}
$$

(Hartono, 2013)

Keterangan:

ATVA $_{\text {before }}=$ rata-rata volume perdagangan saham sebelum Pelantikan Presiden

$\mathrm{ATVA}_{\text {after }}=$ rata-rata volume perdagangan saham setelah Pelantikan Presiden

TVA $_{\text {before }}=$ aktivitas volume perdagangan saham sebelum Pelantikan Presiden

$\mathrm{TVA}_{\text {after }}=$ aktivitas volume perdagangan saham setelah Pelantikan Presiden

$\mathrm{n} \quad=$ jumlah sekuritas

\section{Pengujian Hipotesis}

Dalam pengujian hipotesis ini, peneliti akan menggunakan Uji Wilcoxon pada program SPSS versi 20 for windows. Uji Wilcoxon digunakan untuk membandingkan respons antara dua kelompok data yang saling berhubungan dengan skala data kontinu (Yamin \& Kurniawan, 2009).

\section{Hipotesis 1}

Pengujian pada hipotesis pertama untuk mengetahui apakah ada perbedaan secara signifikan antara reaksi investor sebelum dan sesudah pelantikan presiden, yang ditandai oleh adanya perbedaan abnormal return. 
Penggunaan untuk tingkat signifikan $(\alpha)$ ini sebesar 0,05 dan memiliki kriteria dalam pengujian yaitu:

Jika probabilitas $<\alpha$ maka Ho ditolak Jika probabilitas > a maka Ho diterima

\section{Hipotesis 2}

Pengujian hipotesis kedua dilakukan untuk melihat apakah ada perbedaan reaksi investor saat sebelum dan sesudah pelantikan presiden secara signifikan, yang ditandai adanya perbedaan pada aktivitas volume perdagangan saham.

Tingkat signifikan ( $\alpha$ ) yang ditetapkan sebesar 0,05 dengan penentuan kriteria yang digunakan adalah:

Jika probabilitas $<\alpha$ maka Ho ditolak

Jika probabilitas > a maka Ho diterima

\section{HASIL DAN PEMBAHASAN}

Hasil perhitungan Average Commulative Abnormal Return (ACAR)

Hasil perhitungan ini mengalami pergerakan yang berubah-ubah sehingga dapat diketahui bahwa nilai tertinggi dan nilai terendah pada periode $\mathrm{H}-5$ peristiwa pelantikan Presiden yaitu 0,030380405 dan $-0,021697303$. Sedangkan untuk periode $\mathrm{H}+5$ memiliki nilai tertinggi 0,017580963 dan nilai terendah $-0,023204865$. Selain itu, perhitungan nilai rata-rata abnormal return memiliki negative rank dan positive rank. Terdapat 24 data $(\mathrm{N})$ dinyatakan negative rank atau selisih negatif artinya bahwa sejumlah 24 data tersebut mengalami penurunan nilai rata-rata abnormal return. Total penjumlahan ranking negatif sebesar 562,00 dengan rata-rata penurunan sebesar 23,42. Sedangkan untuk 21 data (N) lainnya dinyatakan positive ranks atau selisih positif yang artinya sejumlah 21 data tersebut mengalami peningkatan nilai ratarata abnormal return. Jumlah ranking yang dinyatakan positif sebesar 473,00 dan ratarata peningkatan yang terjadi sebesar 22,52 . Secara keseluruhan tidak terdapat nilai rata-rata yang sama antara $\mathrm{H}-5$ dan $\mathrm{H}+5$ pelantikan Presiden.

Hasil Perhitungan Average Trading Volume Activity (ATVA)

Hasil perhitungan ini memiliki pergerakan yang bervariasi sehingga hal tersebut akan mempermudah dalam penentuan nilai rata-rata tertinggi dan terendah. Untuk periode sebelum peristiwa pelantikan Presiden memiliki nilai tertinggi sejumlah 0,20792765 dan nilai terendah sejumlah 0,000300865 . Sedangkan pada periode sesudah peristiwa pelantikan Presiden nilai tertinggi dan terendah sebesar 0,008936828 dan 0,000293861. Perhitungan nilai rata-rata trading volume activity (ATVA) tersebut memiliki negative rank dan positive rank. Negative rank atau selisih (negatif) memiliki 17 jumlah data artinya sejumlah 17 data tersebut mengalami penurunan. Adapun jumlah ranking dalam kelompok negatif sebesar 410,00 dan rata-rata yang dimiliki akibat terjadinya penurunan tersebut sebesar 24,12 . Sedangkan untuk positive ranks atau selisih (positif) memiliki 28 data (N) dengan maksud sejumlah 28 data tersebut mengalami peningkatan. Jumlah ranking positif atau sum of ranks yaitu 625,00 dan rata-rata peningkatan tersebut sebesar 22,32. Dari keseluruhan nilai rata-rata pada trading volume activity tidak ada nilai yang sama antara $\mathrm{H}-5$ dan $\mathrm{H}+5$ peristiwa pelantikan Presiden.

Hasil Analisis Data Average Commulative Abnormal Return (ACAR) Sebelum dan Sesudah Peristiwa

Pengujian analisis data ini bertujuan untuk membuktikan bahwa ada atau tidak perbedaan dari nilai rata-rata abnormal return yang diterima oleh pihak investor pada periode sebelum dan sesudah peristiwa pelantikan Presiden.

Tabel 1. Hasil Uji Wilcoxon untuk Average Commulative Abnormal Return

\begin{tabular}{|c|c|}
\hline Keterangan & Nilai \\
\hline Z & $-0,502$ \\
\hline $\begin{array}{l}\text { Asymp. Sig. (2- } \\
\text { tailed) }\end{array}$ & 0,615 \\
\hline
\end{tabular}

Berdasarkan hasil pengujian wilcoxon di atas menunjukkan bahwa nilai $Z$ skor pada hasil output "Test statistic" sebesar $-0,502$. Untuk taraf signifikansi atau nilai alfa $(\alpha)$ yang digunakan sebesar $5 \%$. Nilai probabilitas sebesar 0,615 sehingga nilai tersebut diatas $0,05(0,615>0,05)$ 
maka Ho diterima dan hasil uji ini dinyatakan tidak signifikan secara statistik artinya pada abnormal return tidak memiliki perbedaan secara signifikan pada sebelum dan sesudah pelantikan Presiden ke-8.

Hasil Analisis Data Average Trading Volume Activity (ATVA) Sebelum dan Sesudah Peristiwa

Pada analisis data average commulative trading volume activity (ATVA) yang dilakukan untuk membuktikan apakah ada perbedaan saat sebelum dan sesudah peristiwa pelantikan Presiden yang dilihat dari perolehan nilai rata-rata trading volume activity.

Berdasarkan pada analisis uji Wilcoxon menunjukkan bahwa nilai $Z$ skor pada output "Test Statistic" sebesar -1,213. Untuk taraf signifikansi atau nilai alfa $(\alpha)$ yang digunakan sebesar 5\%. Nilai probabilitas yang didapat sebesar 0,225 sehingga nilai ini dinyatakan lebih besar dari $0.05(0,225>0,05)$ maka Ho diterima. Hasil pengujian ini dinyatakan tidak signifikan secara statistic artinya tidak terdapat perbedaan pada volume aktivitas perdagangan saham.

Tabel 2. Hasil Uji Wilcoxon untuk Average Trading Volume Activity (ATVA)

\begin{tabular}{ll}
\hline \multicolumn{1}{c}{ Keterangan } & Nilai \\
\hline$Z$ & $-1,213$ \\
\hline $\begin{array}{l}\text { Asymp. Sig. (2- } \\
\text { tailed) }\end{array}$ & 0,225 \\
\hline
\end{tabular}

\section{Pembahasan}

Berdasarkan pada hasil analisis uji statistic menggunakan pengujian wilcoxon bahwa secara signifikan antara abnormal return dan aktivitas volume perdagangan saham masing-masing tidak memiliki perbedaan pada periode sebelum $(\mathrm{H}-5)$ dan sesudah $(\mathrm{H}+5)$ pelantikan Presiden. Penyebab dari tidak munculnya perbedaan secara signifikan pada abnormal return ini karena pihak investor tidak bereaksi secara berlebihan terhadap peristiwa tersebut sehingga tidak memiliki kandungan informasi dan nantinya akan berpengaruh pada penentuan pengambilan keputusan dalam melakukan kegiatan investasi. Pihak investor juga masih bertindak wait and see yang menganggap bahwa hal ini tidak berdampak kepada harga saham dan pergerakannya di pasar modal (Pratama, 2015). Tindakan wait and see dari pihak investor terhadap pengambilan suatu keputusan untuk berinvestasi menyebabkan tidak adanya reaksi pasar secara signifikan. Reaksi pasar dapat terjadi secara signifikan apabila peristiwa yang terjadi bersifat tak terduga atau mendadak dimana para investor tidak bisa melakukan tindakan antisipasi atas peristiwa yang terjadi (Nuryana, 2016). Disisi lain, pihak investor juga tidak mendapatkan keuntungan lebih selain dari keuntungan sesungguhnya (actual return) sehingga menyebabkan abnormal return tidak memiliki perbedaan pada saat sebelum dan sesudah peristiwa.

Selain itu, pada volume aktivitas perdagangan saham juga dinyatakan secara signifikan tidak memiliki perbedaan hal ini disebabkan oleh tidak terjadinya peningkatan volume aktivitas perdagangan saham di pasar modal secara besarbesaran, sehingga peristiwa tersebut tidak mempengaruhi harga saham di pasar modal. Pihak investor menilai peristiwa tersebut tidak mengandung informasi dan hal ini berdampak pada tindakan investor untuk mengambil keputusan perdagangan secara normal. Selain itu, terjadinya penurunan permintaan saham akan berpengaruh pada aktivitas volume perdagangan saham yang semakin kecil dan berdampak pada harga saham dan return saham juga akan mengalami penurunan. Sehingga penjelasan tersebut didukung oleh Chordia \& Baskaran (2000) bahwa dalam memperoleh return saham yang tinggi disebabkan oleh saham dengan volume perdagangan yang tinggi pula.

Menurunnya volume aktivitas perdagangan saham mengindikasikan bahwa jumlah pihak investor sedikit atau bahkan masih banyak pihak investor tidak tertarik untuk melaksanakan kegiatan berinvestasi di pasar modal. Akibat dari terjadinya penurunan jumlah volume pada aktivitas perdagangan saham ini dapat menimbulkan sikap ketidakpercayaan dari pihak pelaku pasar modal untuk waktu yang yang datang. Sedangkan peningkatan 
volume aktivitas perdagangan saham mengindikasikan bahwa banyaknya jumlah investor yang melakukan kegiatan transaksi jual beli saham. Volume saham yang mengalami peningkatan dibarengi oleh perbedaan kesepakatan yang disebabkan oleh pandangan pihak investor yang berbeda-beda terhadap informasi peristiwa yang telah diumumkan ke publik (Cahyono, 2014).

Adapun beberapa faktor yang dapat menyebabkan tidak adanya perbedaan abnormal return dan trading volume activity salah satunya disebabkan oleh peristiwa politik yang terjadi. Peristiwa politik ini menjadi salah satu bahan pertimbangan yang dilakukan pihak investor dalam pengambilan keputusan saat berinvestasi. Peristiwa pelantikan Presiden cukup berpengaruh besar terhadap reaksi investor untuk berinvestasi. Seperti yang telah diketahui bahwa Joko Widodo telah memenangkan pemilihan umum Presiden Republik Indonesia selama dua periode berturut-turut yaitu untuk periode yang pertama di mulai dari tahun 2014-2019 dan periode kedua di mulai dari tahun 20192024. Pada tahun 2014 merupakan awal dari puncak popularitas istilah Jokowi Effect dikenal. Hal ini disebabkan oleh kemenangan Joko Widodo sebagai Presiden RI dan mampu mempengaruhi harga saham sehingga meningkat tajam di pasar modal. Sebaliknya pada kemenangan Joko Widodo sebagai Presiden RI periode kedua tahun 2019, istilah Jokowi Effect sudah mulai menurun. Hal tersebut dikarenakan tingkat antusiasme para investor mulai menurun terhadap kemenangan Joko Widodo yang sudah tidak seperti awal kemunculan Joko Widodo sebagai pemenang pemilihan Presiden pada tahun 2014. Dari penjelasan diatas, untuk lebih memperkuat hasil dari peristiwa ini, maka peneliti Ayu \& Prameswari (2018); Pratama (2015) menyatakan bahwa tidak semua peristiwa politik terjadi dapat menyebabkan adanya reaksi dari para pelaku pasar modal di Indonesia. Disisi lain, adanya kemunculan berbagai isu yang menggiring opini tentang respon positif pasar atas kemenangan yang diperoleh Joko Widodo sudah diterima oleh pihak investor saat pengumuman resmi yang disampaikan oleh KPU terkait hasil akhir pilpres. Sehingga ketika peristiwa pelantikan presiden terjadi, pihak investor menganggap bahwa peristiwa tersebut sudah tidak mempunyai kandungan informasi lagi.

Selain itu, dengan adanya perkembangan teknologi yang semakin canggih pihak investor dapat dengan cepat dan mudah dalam mengakses informasi yang diinginkan. Banyaknya sarana yang tersedia untuk dapat menggali informasi dan salah satunya adalah Bursa Efek Indonesia serta situs resmi lainnya yang dapat mendukung informasi tentang pasar saham. Informasi yang dimaksudkan adalah berupa laporan keuangan perusahaan go public, profil perusahaan terkait, dll. Sehingga dengan adanya banyak sarana yang dapat membantu pihak investor untuk menemukan informasi yang diinginkan dan hal tersebut akan dijadikan sebagai bahan pertimbangan dalam pengambilan keputusan yang tepat dilakukan oleh pihak investor dalam berinvestasi.

Penelitian ini memiliki hasil yang selaras dengan temuan dari penelitian terdahulu yaitu Nuryana (2016) meneliti tentang peristiwa pengangkatan Joko Widodo sebagai Presiden RI dengan menggunakan 10 hari periode pengamatan peristiwa. Adapun penelitian lain yang dilakukan oleh Indah, Dewi, \& Mawardi (2018) dengan meneliti peristiwa Aksi Bela Islam 4 November 2016. Selain itu, terdapat juga penelitian dengan hasil yang sama dari Parmadi (2014) yang meneliti reaksi investor terhadap kenaikan harga bahan bakar minyak di Bursa Efek Indonesia. Hasil penelitian dari ketiga peneliti diatas menyimpulkan bahwa hasil penelitian yang telah dilakukan tidak menimbulkan reaksi investor dan tidak adanya perbedaan.

\section{SIMPULAN DAN SARAN}

Simpulan

Berdasarkan pada hasil analisis yang telah dilakukan, maka dapat disimpulkan bahwa abnormal return dan aktivitas volume perdagangan saham tidak menimbulkan adanya perbedaan pada periode sebelum dan sesudah peristiwa pelantikan Presiden ke-8. 
Saran

Berdasarkan pada hasil simpulan di atas, penulis dapat mengajukan beberapa saran yaitu untuk pihak investor yang ingin melakukan kegiatan investasi diharapkan untuk mempertimbangkan kembali keputusan yang akan diambil dengan melakukan analisis terlebih dahulu terhadap informasi yang dipublikasikan agar pihak investor mendapatkan return secara maksimal. Untuk peneliti selanjutnya bisa mengembangkan variabel-variabel lain seperti periode menahan (holding period), dan bid-ask spread. Selain itu untuk peneliti selanjutnya diharapkan untuk menggunakan model perhitungan yang berbeda, sehingga dapat dijadikan bahan pembanding.

\section{DAFTAR PUSTAKA}

Alrhafynza, F. B., \& Siswanto, E. (2017). Reaksi Pasar Modal Indonesia Terhadap Peristiwa Politik Nasional (Studi Pada Saham LQ45 Atas Putusan Sidang Kasus Penistaan Agama Oleh Gubernur DKI Jakarta, Basuki Tjahaja Purnama Tahun 2017). 47-57.

Arikunto, S. (2002). Prosedur Penelitian: Suatu Pendekatan Praktek. Retrieved from PT Rineka Cipta

Ayu, I., \& Prameswari, N. (2018). Analisis Reaksi Pasar Modal Pada Peristiwa Pemilihan Gubernur DKI Jakarta Tahun 2017. 22, 944-975.

Cahyono, T. Y. (2014). Volume Perdagangan dan Return Saham Dalam Hubungannya dengan Bid-Ask spread Pada Perusahaan Go Publik.

Chordia, T., \& Baskaran, S. (2000). Trading Volume and Cross Autocorelation in Stock Return. The Journal of Finance, 55(2), 913-936.

Diniar, A. H., \& Kiryanto. (2015). Analisis Dampak Pemilu Presiden Jokowi Terhadap Return Saham (Studi Kasus Saham LQ-45 di Bursa Efek Idonesia). 4(2), 97-108.

Fama, E. F. (1991). Effcient Capital Market: II. The Journal of Finance, XLVI(5).

Hartono, J. (2000). Teori Portofolio dan Analisis Investasi (2nd ed.). Jogjakarta: BPFE.
Hartono, J. (2010). Teori Portofolio dan Analisis Investasi (7th ed.). Jogjakarta: BPFE.

Hartono, J. (2013). Teori Portofolio dan Analisis Investasi (8th ed.). Jogjakarta: BPFE.

Hartono, J. (2014). Teori Portofolio dan Analisis Investasi (9th ed.). Jogjakarta: BPFE.

Indah, M., Dewi, A., \& Mawardi, M. C. (2018). Reaksi investor dalam pasar modal terhadap peristiwa aksi bela islam 4 november 2016 di jakarta. 07(07), 60-72.

Kurniawan, H. (2010). Analisis Pengaruh Kunjungan Presiden Amerika Serikat Barack Obama ke Indonesia Terhadap Indeks Saham LQ45 (Studi di Bursa Efek Indonesia). Kajian Bisnis STIE Widia Manggala Yogyakarta, 13(2), 218-230.

Mansur, F., \& Jumaili, S. (2014). Reaksi Pasar Modal Terhadap Peristiwa Pemilihan Umum Tahun 2014 Pada Perusahaan Terdaftar di Bursa Efek Indonesia. Jurnal Penelitian Universitas Jambi Seri Humaniora, 16(2), 59-68.

Meidawati, N., \& Mahendra, H. (2004). Pengaruh Pemilihan Umum Legislatif Tahun 2004 Terhadap Return Saham dan Volume Perdagangan Saham. 7(1), 113-125.

Mulyono, S. (2000). Pengaruh Earning Per Share (Eps) dan Tingkat Bunga Terhadap Harga Saham. Jurnal Ekonomi Dan Manjemen, 1(2).

Nuryana, I. (2016). Analisis Reaksi Pasar Modal Terhadap Pengangkatan Joko Widodo Sebagai Presiden Republik Indonesia. Jurnal IImu Manajemen Dan Akuntansi, 4(2), 1-9.

Parmadi, A. (2014). Analisis Reaksi Investor Terhadap Kenaikan Harga Baham Bakar Minyak di Bursa Efek Indonesia ( Event Study Terhadap Kenaikan Harga BBM Pada 21 Juni 2013 di Indonesia ). 1(July 2013).

Pratama, I. G. B. (2015). Reaksi Pasar Modal Indonesia Terhadap Peristiwa Politik ( Event Study pada Peristiwa Pelantikan Joko Widodo Sebagai Presiden Republik Indonesia Ke-7 ). 3(13). 
Ramesh, \& Rajumesh. (2015). Stock Market Reaction to Political Events: A Study of Listed Companies in Colombo Stock Exchange of Sri Lanka. Jurnal of Economics and Sustainable Development, 6(3), 131-140.

Sasongko, J. (2015). Reaksi Pasar Modal Atas Peristiwa Pengumuman Presiden RI 2014 (Studi Pada Saham Sektor Pertambangan di Bursa Efek Indonesia). 12(1), 33-44.

Sihotang, E. M., \& Mekel, P. A. (2014). Reaksi Pasar Modal Terhadap Pemilihan Umum Presiden Tanggal 9 Juli 2014 di Indonesia. 3(1), 951-960.

Suherman, Nuraisyah, R., \& Ahmad, G. N. (2016). Abnormal Return dan Likuiditas Saham Atas Pengumuman Akuisisi. Jurnal Manajemen, $X X(1)$, 151-168.

Suryawijaya, M. A., \& Setiawan, F. A. (1998). Reaksi Pasar Modal Indonesia Terhadap Peristiwa Politik Dalam Negeri (Event Study Pada Peristiwa 27 Juli 1996). Kelola, VII(18), 137-153.

Tandelilin, E. (2001). Analisis Investasi dan Manajemen Portofoli. Jogjakarta: BPFE.

Waterschoot, J. (2013). An Empirical Study on The Impact of The U.S Presidencial Election on The U.S Stock Market. University, Journal Economic and Management Finance Department Tiburg, 8(2), 153-169.

Wulan, D. C., Handayani, S. R., \& Nurlaily, F. (2018). Analisis Abnormal Return dan Trading Volume Activity Terhadap Pengumuman Unusual Market Activity ( Studi pada Perusahaan yang Terdaftar dalam Pengumuman Unusual Market Activity di BEI Tahun 2015-2017). 61(1), 173-180.

Yamin, S., \& Kurniawan, H. (2009). SPSS Complete: Teknik Analisis Statistik Terlengkap dengan Software SPSS. Jakarta: Salemba Infotek. 